\title{
COMPUTER SELF-EFFICACY OF PROSPECTIVE PHYSICAL EDUCATION TEACHERS
}

Hüseyin Ünlü, Emin Süel

Aksaray University

Highlights
- $\quad$ Physical education and Sport
- $\quad$ Educational Technology
Computer Self-Efficacy

\section{Abstract}

This study investigated the computer self-efficacy of Turkish prospective physical education teachers. The research group consisted of 173 prospective physical education teachers. In the study "Computer SelfEfficacy Perception Scale" was used as data collection tool. Results indicated that prospective physical education teachers obtained high computer self-efficacy scores. Prospective physical education teachers' computer self-efficacy was also examined according to their gender and class year no significant difference was found. In the study it has also found that no significant correlation between prospective physical education teachers' computer self-efficacies and their ages. In addition there was significant difference in the scale of computer self-efficacy perception based on the owner of a computer.

Keywords

Technology, university student, physical education and sport
Article type

Full research paper

Article history

Received: June 4, 2014

Received in revised form: June 18, 2014

Accepted: July 7, 2014

Available on-line: July 31, 2014

Hüseyin Ü, and Süel E. (2014) "Computer Self-Efficacy of Prospective Physical Education Teachers", Journal on Efficiency and Responsibility in Education and Science, Vol. 7, No. 2, pp. 33-36, online ISSN 1803-1617, printed ISSN 1803-1617, doi: 10.7160/eriesj.2014.070202.

\section{Introduction}

Technology has made a remarkable impact on society, especially in the education arena. The teaching and learning process has recently been altered by the convergence of a variety of technological, instructional, and pedagogical developments (Bonk and King, 1998). One of these technological tools is computers. Computers are common tools in most schools, and are being used increasingly in all subject areas (KhorramiArani, 2001).

Being common tools in most schools, computers are used increasingly in all subject areas. Especially in universities, teachers' expectations from students regarding their computer abilities have been increasing. Majority of teachers do not accept hand written projects; instead, they usually prefer presentations prepared on computers, and they also expect their students to do further studies, comparisons of their subject with different authors results (İşman and Çelikli, 2009). Although some students are enthusiastic about using computers, others may be more apprehensive. In so far as computers aid learning and are common tools in the workforce, it is crucial for all students to become familiar and comfortable with their use (KhorramiArani, 2001).

Among the various individual factors examined in past research, computer self-efficacy (CSE) has been identified as a key determinant of computer-related ability and use of computers (Hasan, 2003).

The continuous increase of efficacy and importance of computer and computer products in learning-teaching processes is also important for features of teachers, who will use these technologies. Computer self-efficacy of teachers who will use computer is very important for the use of this technology (Aşkar and Umay, 2001). Computer self-efficacy was also found to be associated with attitudes toward computer technologies (Zhang and Espinoza, 1998).

Computer self-efficacy is a specific type of self-efficacy. Compeau and Higgins (1995) defined computer self-efficacy as "a judgment of one's capability to use a computer" (p. 192). Studies showed that higher levels of computer self-efficacy corresponded to increased performance in computer courses and a greater achievement of computer competency (KhorramiArani, 2001).

Computer self-efficacy has been investigated in education contexts including university students especially who educated teacher education programs (Karsten and Roth, 1998; Aşkar and Umay, 2001; Akkoyunlu and Kurbanoğlu, 2003; Yusuf, 2005; Özçelik and Aşkım-Kurt, 2007; Kao and Tsai, 2009).

These studies generally focus on determining university students' and prospective teachers' belief on computer self-efficacy according to the variables. In addition, the relationship between attitudes toward and self-efficacy regarding the computer and/ or the Internet has been examined in many previous studies. The studies in the field showed that individuals whose computer selfefficacy levels are higher are more desirous about and interested in using computer and they have higher expectations from kind of studies. In addition, when these individuals encounter difficulty in any of the computer; they can easily cope with it (Karsten and Roth, 1998; Akkoyunlu and Orhan, 2003).

Use of computer during the educational process will enable the process to be more effective and efficient. Computer usage levels and computer self-efficacy of physical education teachers, who are the executives of physical education lesson that is an inseparable and important part of the general education, are important, in terms of the process of teaching-learning. Use of 
computer by physical education teachers is among important features to be possessed by physical education teachers, in line with the sense of the developing education. Computer selfefficacy of physical education teachers will bring along the desire and eagerness to use computer. Besides, the determination and development of computer self-efficacy of prospective physical education teachers is also important for physical education teachers to use computer and educational technologies in educational activities. This paper is extension of Ünlü and Suel (2012). The aim of this study is to determine the computer selfefficacy of prospective physical education teachers.

\section{Methods}

\section{Research Model and Sample}

The research was conducted using a descriptive research model for determining the prospective physical education teachers' computer self-efficacy. The research group was consisted of 173 prospective physical education teachers who were enrolled in various years (1- 4 class) of physical education and sports teaching programs at 3 universities during the 2010-2011 school year.

In terms of gender, $76(43.9 \%)$ of participants were female, and $120(56.1 \%)$ of whom were male. The ages of the students ranged between 18 and 31 years, and the average age was 21.96 \pm 2.43 years. The grade level of participant, $26.6 \%(n=46)$ of participants were freshman, $28.3 \%(n=49)$ were sophomore, $26.6 \%(n=46)$ were junior, and $18.5 \%(n=36)$ were in the senior. Also in the research group while $139(\%$ 80.3) prospective physical education teacher have the owner of a computer, 34 (\%19.7) have not the owner.

Participants were drawn via purposive sampling. By considering the study's main purpose samples were chosen, "enrollment in physical education and sports teaching programs", via maximum variability method in the types of purposive sampling. This sampling method is give important clues about the values of population (Fraenkel \& Wallen, 1993).

\section{Instruments}

In this study, two scales were used to collect data. In the first scale, which was developed by the researcher in order to define the demography of participants, gender and class year were included. The second scale is "Scale of Computer Self-Efficacy Perception". Scale of computer self-efficacy perception was developed by Aşkar and Umay (2001) and it involves 18 items which 7 of them were scored in the reserve direction in the scale.

Reliability coefficient of the scale is 0.71 . Cronbach's alpha was calculated as 0,83 in the study. It is designed as a 5-point Likert scale with response categories of: always, usually, sometimes, rarely, and never. While the positive items of the 5-point likert scale are scored as "always 5 - never 1", negative items are scored inverse as "never 5 - always 1 ".

\section{Data Analysis}

Descriptive statistical techniques were used in the data analysis. At the same time when it was seen that the variances displayed a homogenous distribution, t-test was used for independent groups in order to determine the prospective physical education teachers' computer self-efficacy in terms of gender variable. In addition One-way Anova was used in the comparisons in terms of grade levels. The significance level was taken as 0.05 in the comparisons $(\mathrm{p}<0.05)$.

\section{Results}

In this part of the research, presented findings related to prospective physical education teachers' computer self-efficacy and their efficacies a terms of gender, year of class and owner of a computer. Also it was presented correlation between prospective physical education teachers' computer self-efficacy and their ages.

Findings concerning standard deviation values and the mean values that prospective physical education teachers obtained in the whole of the scale of computer self-efficacy perception the study group ( $\mathrm{n}=173)$ was found as $\bar{X}=3.24(\mathrm{SS} \pm .285)$.

$\mathrm{t}$ - test (Independent Samples t test) was carried out in order to determine if there were any differences between prospective physical education teachers' computer self-efficacy in terms of the "gender" variable. The results are presented in Table 2.

Table 1. Comparison of prospective physical education teachers' computer self-efficacies in terms of the variable of gender.

\begin{tabular}{ccccccc}
\hline Gender & $\mathbf{N}$ & $\bar{X}$ & SD & T & df & $\mathbf{p}$ \\
\hline Female & 76 & 3.29 & .285 & 2.078 & 171 & .455 \\
Male & 97 & 3.20 & .280 & & & \\
\hline
\end{tabular}

As displayed in Table 1, which involves the comparison of computer self-efficacy of prospective physical education teachers in terms of the variable of gender, it was observed that while female prospective physical education teachers obtained an average of $\bar{X}=3.29$, male prospective physical education teachers obtained an average of $\bar{X}=3.20$. Accordingly, no significant difference was observed in the scale of computer self-efficacy perception based on gender.

One-way ANOVA was carried out in order to determine the prospective physical education teachers' computer self-efficacy in terms of the "year of class" variable. The results are presented in Table 3.

Table 2. Comparison of prospective physical education teachers' computer self-efficacies in terms of the variable of class year.

\begin{tabular}{lcccccc}
\hline Class year & N & $\bar{X}$ & SD & df & $\mathbf{f}$ & $\mathbf{p}$ \\
\hline 1. Freshman & 46 & 3.18 & .285 & & & \\
2. Sophomore & 49 & 3.24 & .248 & 3 & & \\
3. Junior & 46 & 3.26 & .311 & 169 & .883 & .451 \\
4. Senior & 32 & 3.27 & .302 & 172 & & \\
5. Total & 173 & 3.24 & .285 & & & \\
\hline
\end{tabular}

The prospective physical education teachers' computer selfefficacy in terms of their years of classes were given in Table 2. It can be seen that the prospective physical education teachers had the highest mean at the senior class $\left(4^{\text {th }}\right)$ with $\bar{X}=3.27$ and prospective physical education teachers who were freshman $\left(1^{\text {st }}\right)$ had the lowest mean. There were no significant differences observed in the comparisons according to the prospective physical education teachers' years of class.

$\mathrm{t}$ - test (Independent Samples $\mathrm{t}$ test) was carried out in order to determine if there were any differences between prospective physical education teachers' computer self-efficacy in terms of the "owner a computer" variable. The results are presented in Table 3.

Table 3. Comparison of prospective physical education teachers' computer self-efficacies in terms of the variable of owner a computer. 


\begin{tabular}{lcccccc}
\hline $\begin{array}{l}\text { Owner a } \\
\text { Computer }\end{array}$ & N & Mean & Sd & $\mathbf{t}$ & df & $\mathbf{p}$ \\
\hline Owner & 139 & 3.27 & .278 & 2.831 & 171 & .005 \\
Non-owner & 34 & 3.11 & .285 & & & \\
\hline
\end{tabular}

With reference to Table 3, prospective physical education teachers who owner a computer obtained an average of $\bar{X}=$ 3.27 and who have not the owner of a computer obtained an average of $\bar{X}=3.11$. It was seen that there were significant difference in the scale of computer self-efficacy perception based on the owner of a computer.

Person Coefficient Correlation Test was carried out in order to determine if there were any correlation between prospective physical education teachers' computer self-efficacy and their ages. The results are presented in Table 4.

Table 4. Correlation of prospective physical education teachers' computer self-efficacies in terms of the variable of ages.

\begin{tabular}{lcc}
\hline Computer Self-Efficacy and Age & Age & Total Mean \\
\hline Pearson Correlation & 1 & -.101 \\
Sig. (2-tailed) & & .188 \\
N & 173 & 173
\end{tabular}

In Table 4, correlation between prospective physical education teachers' computer self-efficacies and their ages were presented. Accordingly, no significant correlation was observed between prospective physical education teachers' computer selfefficacies and their ages $(r=-.101 \mathrm{p}>0.05)$.

\section{Discussion}

Computer self-efficacy of prospective physical education teachers was examined in the study. It was observed that prospective physical education teachers obtained an average of $\bar{X}=3.24$ from the scale of computer self-efficacy beliefs. Accordingly, it could be argued that prospective physical education teacher's had the high computer self-efficacy.

Computer self-efficacy studies, which used student subjects at a university level, showed that higher levels of computer selfefficacy corresponded to increased performance in computer courses and a greater achievement of computer competency (Karsten and Roth, 1998; Langford and Reeves, 1998).

Studies demonstrated that computer self-efficacy has an impact on increasing the performance and the technological innovation of employees, reducing computer induced anxiety, and promoting higher occupational positions (Compeau and Higgins, 1995; Harrison and Rainer, 1997).

In the study another result that is obtained is related with the self-efficacy of prospective physical education teachers, in terms of the variable of gender. Accordingly, no significant difference was observed among computer self-efficacy of prospective physical education teachers, in terms of the variable of gender.

Research on computer self-efficacy also revealed that males on average have better computer self-efficacy than females in general (Brosnan and Lee, 1998; Işman and Çelikli, 2009; Torkzadeh and Koufteros, 1994). But in some other studies that were performed on university students; Adalier (2012), Çağırgan-Gülten et al. (2011) and Sam, Othman and Nordin (2005) observed no significance difference among computer self-efficacy in terms of the variable of gender.

Another result that is obtained from the study is related with the computer self-efficacy of prospective physical education teachers, in terms of their class levels. Accordingly, no significant difference was found on the computer self-efficacies of prospective physical education teachers, in terms of the variable of class. A similar study result was encountered in the study, which was performed by Yilmaz et al (2006). Besides, in the study that was performed by Gerçek et al (2006) and had a significance level of 0.01 , it was observed that there was no significant difference between the computer self-efficacies of prospective teachers. These results were observed to have supported the result obtained from the study. However, in the studies performed by Zehir-Topkaya (2010) and Akkoyunlu and Kurbanoğlu (2003), it was observed that the variable of class formed a significant difference. This result that was obtained from the study could generally be explained with the fact that prospective physical education teachers start using computer at an early age and use of computer becomes widespread.

In the comparisons made according to prospective physical education teachers' whether owner a computer, it was seen that prospective physical education teachers who had owner a computer had higher computer self-efficacy than the who did not owner a computer. In the study which was carried out by Özçelik and Aşkım-Kurt (2007) also found those primary school teachers who have the personal computer had higher self-efficacy. This result supports the findings obtained in the present research.

According to this result it can be argued that prospective physical education teachers who have the owner of the computer have the opportunity whenever they need this may be cause to their higher computer self-efficacy.

The latest result of the study was related correlation between prospective physical education teachers' computer self-efficacy and their ages. In the study it was not observed significant correlation prospective physical education teachers' computer self-efficacy and their ages. Akkoyunlu and Orhan (2003) in their studies was found that significant differences in the comparison of computer self-efficacy of students and their ages also stated that the increasing of the students' ages increasing of the computer self-efficacy. In another study Özçelik and AşkımKurt (2007) argued that computer self-efficacy differentiate according to the age, and in their studies was stated that teacher who were the between 20-25 had the highest self-efficacy and teachers who were the 40-45 had the lowest computer selfefficacy. These studies were not consistent with present study.

According to this result, the were no relationship between computer self-efficacy and ages, the average age of the prospective physical education teacher had lowest and it can be thought that they have the similar experiences about the computer.

\section{Conclusion}

Self-efficacy is a subject that has significantly been emphasized in education especially in recent years. It is known that individuals with a high perception of self-efficacy trust their own skills more to achieve a goal and they have a greater faith to succeed. Common use of computers during the educational process will increase the performance in the process of teaching. From this aspect, computer self-efficacy of prospective physical education teachers will make positive contributions to the educational process during the physical education lesson. This study determined the computer self-efficacy perceptions of prospective physical education teachers. In the study it can be concluded that computer self-efficacy of prospective physical 
education teachers was at a high level. While there were no significance differences according to the gender and class level between computer self-efficacy; it was found that significant differences owner a computer between computer self-efficacy. In addition any significant correlation was observed between prospective physical education teachers' computer selfefficacies and their ages.

Future studies will be carry out large population and use another variable such as computer experiences, giving course etc. Additionally, it might also discuss how to increase the computer self-efficacy of prospective physical education teachers.

\section{References}

Adalier, A. (2012) 'Turkish and English language teacher candidates' perceived computer self-efficacy and attitudes toward computer', The Turkish Online Journal of Educational Technology, 11 (1):192-201.

Akkoyunlu, B. and Kurbanoğlu, S. (2003) 'Öğretmen Adaylarının Bilgi Okuryazarlığı ve Bilgisayar Öz-Yeterlik Algıları Üzerine Bir Çalışma', Hacettepe Üniversitesi Eğitim Fakültesi Dergisi, no. 24, pp. 1-10.

Akkoyunlu, B. and Orhan, F. (2003) 'Bilgisayar ve Öğretim Teknolojileri Eğitimi Bölümü Öğrencilerinin Bilgisayar Kullanma Öz-Yeterlik İnancı ile Demografik Özellikleri Arasındaki İlişki' The Turkish Online Journal of Educational Technology, no. 9, pp. 1.

Aşkar, P. and Umay, A. (2001) 'İlköğretim matematik öğretmenliği örgencilerinin bilgisayarla ilgili öz-yeterlik algısı', Hacettepe Üniversitesi Eğitim Fakültesi Dergisi, no. 21, pp. 1-8.

Bonk, C. J. and King, K. S. (1998) Electronic collaborators: Learner centered technologies for literacy, apprenticeship, and discourse. Mahwah: Lawrence Erlbaum.

Brosnan, M. and Lee, W. (1998) 'A cross-cultural comparison of gender differences in computer attitudes and anxiety: The UK and Hong Kong', Computers in Human Behavior, no.14, vol. 4, pp. 559-577.

Compeau, D. R. and Higgins, C.A. (1995) 'Computer selfefficacy: Development of a measure and initial test', MIS Quarterly, June, 89-211.

Çağırgan-Gülten, D., Yaman, Y., Deringöl, Y., and Özsari, İ. (2011) 'Investigating the relationship between curiosity level and computer self-efficacy beliefs of elementary teachers candidates', The Turkish Online Journal of Educational Technology, no.10, vol. 4, pp.248-254.

Gerçek, C., Köseoglu, P., Yilmaz, M., and Soran, H. (2006) 'Öğretmen adaylarının bilgisayar kullanımına yönelik tutumlarının çeşitli değişkenler açısından incelenmesi', Hacettepe Üniversitesi Eğitim Fakültesi Dergisi, no. 30, pp. 130-139.

Fraenkel, J. R., \& Wallen, N. E. (1993) How to design and evaluate research in education. New York: Mcgraw-Hill.

Harrison, A.W. and Ranier, K. (1997) 'The influence of individual differences on skill in end-user computing', Journal of Management Information Systems, no. 9, vol. 1, 93-111.

Hasan, B. (2003) 'The influence of specific computer experiences on computer self-efficacy beliefs', Computers in Human Behavior, no. 19, vol. 4, pp. 443-450.
İşman, A. and Çelikli, G. E. (2009) 'How does student ability and self-efficacy affect the usage of Computer technology?', The Turkish Online Journal of Educational Technology, no. 8, pp. 1.

Kao, C. P. and Tsai, C. C. (2009) 'Teachers' attitudes toward web-based professional development, with relation to Internet self-efficacy and beliefs about web-based learning', Computers \& Education, 53 (1): 66-73.

Karsten, R. and Roth, R. (1998) 'Computer self-efficacy: A practical indicator of student computer competency in introductory IS courses', Informing Science, no. 1 vol. 3, pp. 6168.

Khorrami-Arani, O. (2001) 'Researching computer selfefficacy', International Education Journal, no. 2, vol. 4, pp. $17-25$.

Langford, M. and Reeves, T. E. (1998) 'The relationship between computer self-efficacy and personal characteristics of the beginning information systems student', Journal of Computer Information Systems, no. 38, vol. 4, pp. 41-45.

Sam, H. K., Othman, A. E. A., and Nordin, Z. S. (2005) 'Computer Self-Efficacy, Computer Anxiety, and Attitudes toward the Internet: A Study among Undergraduates in Unimas', Educational Technology \& Society, no. 8, vol. 4, pp. 205-219.

Özçelik, H. and Aşkım-Kurt, A. (2007) 'Primary School Teachers' Computer Self Efficacies: Sample of Balıkesir', Illkögrretim Online, no. 6, vol. 3, pp. 441-451.

Torkzadeh, G. and Koufteros, X. (1994) 'Factorial validity of a computer self-efficacy scale and the impact of computer training', Educational and Psychological Measurement, no. 54, vol. 3, pp. 813-921.

Ünlü, H., and Süel, E. (2012). 'Computer Self-Efficacy of Turkish Prospective Physical Education Teachers', 9th International ERIE Conference $7^{\text {th }}-8^{\text {th }}$ June, Prague, Czech Republic.

Yılmaz, M., Gerçek, C., Köseoğlu, P. and Soran, H. (2006) 'Hacettepe Üniversitesi Biyoloji Öğretmen Adaylarının Bilgisayarla İlgili Öz-Yeterlik İnançlarının İncelenmesi', Hacettepe Üniversitesi Eğitim Fakültesi Dergisi, no. 30, pp. 278-287.

Yusuf, M. O. (2005) 'An Investigation into Teachers' SelfEfficacy in Implementing Computer Education in Nigerian Secondary Schools', Meridian: A Middle School Computer Technologies Journal, no. 8, pp. 2.

Zehir-Topkaya, E. (2010) 'Pre-Service English Language Teachers' Perceptions of Computer Self-Efficacy and General Self-Efficacy', The Turkish Online Journal of Educational Technology, no. 9, vol. 1, pp. 143-156.

Zhang, Y. and Espinoza, S. (1998) 'Relationships among computer self-efficacy, attitudes toward computers, and desirability of learning computing skills', Journal of Research on Technology in Education, no. 30, vol. 4, pp. 420-436. 